\title{
Penguatan Desain Dakwah Masjid di Era Milenilal melalui Android
}

\author{
Jasuri, M Ardhi Khalif, \& Edi Daenuri Anwar \\ Universitas Islam Negeri Islam Negeri Walisongo Semarang \\ Email: jasuri@walisongo.ac.id
}

\begin{abstract}
Dedication work with the title "Design Da'wah Mosque in Millennial Era through Android" uses a community based research (CBR) model, namely by providing assistance in making mosque website design, website management and website content management in eight mosques in Central Java. The meeting point of da'wah that is carried out in the mosque either through recitation, or other forms of activity can be well documented via the internet and can be accessed by Muslims at large. The need for revitalization of the Da'wah Mosque Strategy, revitalization in question is the Da'wah Mosque Strategy is carried out massively, recorded, and uploaded on the mosque website. By uploading it on the website of the mosque, all people in need can download study materials and can see / listen at any time. Of the eight mosques, only two mosques have websites, the Baiturahman Mosque in Semarang and M asjid Agung in Central Java. This assistance resulted in a pretty good design. The website that has been designed by the mosque admin is good with menus and wicets relating to the activities of the mosque preaching. The mosque website is filtered in one "dakwah online" application. Users can enjoy the da'wah of the mosques from the eight mosques in real time effectively and efficiently.
\end{abstract}

Abstrak: Pengabdian dengan topik "Desain Dakwah Masjid di Era Milenial melalui Android" ini menggunakan model community based research (CBR), yaitu dengan melakukan pendampingan pembuatan desain website masjid, pengelolaan website dan manajemen konten website pada delapan masjid di Jawa Tengah. Titik temu dakwah yang dilaksanakan di masjid baik melalui pengajian, maupun bentuk-bentuk kegiatan yang lain bisa didokumentasi dengan baik melalui internet dan dapat diakses oleh umat islam secara luas. Perlu adanya revitalisasi Strategi dakwah masjid, revitalisasi yang dimaksud adalah Strategi dakwah masjid dilakukan secara masif, terdata, dan diunggah dalam website masjid. Dengan diunggah dalam website masjid maka semua masyarakat yang membutuhkan bisa mendownload bahan-bahan pengajian dan bisa melihat/mendengarkan setiap saat. Dari delapan masjid dimaksud hanya dua masjid yang sudah memiliki website yaitu Masjid Baiturahman Semarang dan Masjid Agung Jawa Tengah. Pendampingan ini menghasilkan desain yang cukup baik. Website yang telah di desain oleh admin masjid sudah baik dengan menu 
dan wirget yang berkaitan dengan kegiatan-kegiatan dakwah masjid. Website masjid tersebut tersharing dalam satu aplikasi "dakwah online". User bisa memenikmati dakwah masjid dari delapan masjid tersebut secara realtime dengan efektif dan efisien.

Kata Kunci: Dakwah masjid, dakwah online, community based research

\section{PENDAHULUAN}

Masjid ditinjau dari sejarah memiliki multifungsi, tidak saja sebatas sebagai tempat ibadah, tetapi juga telah difungsikan pada berbagai urusan diantaranya pembinaan sumber daya umat, peningkatan ekonomi, peningkatan kesejahteraan, sosial kemasyarakatan dan lain-lain. Tetapi masjid-masjid saat ini kebanyakan hanya difungsikan untuk menyelenggarakan rutinitas-rutinitas keagamaan seperti ibadah mahdhah, pengajian, maupun peringatan hari besar Islam.

Kegiatan-kegiatan masjid merupakan syiar dakwah bagi masyarakat. Pengajian-pengajian pada beberapa masjid di semarang secara umum sudah baik. Beberapa masjid sudah ada jadwal pengajian secara rutin, dan jadwal pembelajaran TPQ. Namun kebanyakan pengajian dan beberapa kegiatankegiatan tidak terdokumentasi secara baik baik manual maupun digital. Kondisi ini yang menyebabkan bahwa pengajian-pengajian itu hanya terbatas bagi jamaah yang hadir saja pada saat pengajian yang melihat dan mendengar. Sedangkan bagi jamaah rutin masjid tersebut tetapi berhalangan hadir tidak ada sedikitpun manfaat yang diterima apalagi bagi masyarakat yang bukan jamaah tersebut.

Kemajuan teknologi yang di ikuti oleh generasi milenial menyebabakan setiap masyarakat baik anak-anak, muda maupun tua memiliki HP yang sewaktuwaktu bisa mengakses berbagai informasi baik melalui andoid baik Youtube, MP3, video maupun audiovisual dimanapun dan kapanpun.

Kemajuan ini perlu titik temu sehingga dakwah yang dilaksanakan di masjid baik melalui pengajian, maupun bentuk-bentuk kegiatan yang lain terdokumentasi dengan baik melalui internet dan dapat diakses oleh umat islam secara luas. Maka perlu adanya revitalisasi Strategi dakwah masjid, Revitalisasi yang dimaksud adalah Strategi dakwah masjid dilakukan secara masif, terdata, dan diunggah dalam website masjid. Dengan di unggah dalam website masjid maka semua masyarakat yang membutuhkan bisa mendownload bahan-bahan pengajian dan bisa melihat/mendengarkan setiap saat. 
Apabila setiap saat masyarakat setempat dan semua masyarakat dapat mendownload maka secara otomatis pesan-pesan dakwah dapat tersampaikan kepada masyarakat. Keuntungan yang lain seorang ustadz tidak perlu mengulang pengajian dengan materi yang sama kepada masyarakat yang yang membutuhkan.

Manfaat lain masyarakat secara umum dan kaum milenial bisa mengetahui kegiatan masjid dan bisa mengikuti pesan-pesan dakwah. Sehingga pesan dakwah dapat diakses melalui gadget, i-pad dan telekomunikasi lain. Strategi dakwah ini diharapkan membuat pesan dakwah semakin diterima masyarkat secara luas oleh masyarakat. Tujuannya masjid semakin makmur dan masyarakat mencintai masjid serta masyarakat mudah menerima dan pesan-pesan agama melalui website masjid. Sehingga dalam pengabdian ini peneliti mengajukan judul "Revitalisasi Strategi Dakwah Masjid di Era Milenial melalui Android".

\section{METODE DAN KERANGKA TEORI DALAM DAKWAH}

Berdasarkan KKBI, Revitalisasi adalah proses, cara, dan perbuatan menghidupkan kembali suatu hal yang sebelumnya kurang terberdaya. Sedangkan vital di definisikan sangat penting atau perlu sekali (untuk kehidupan dan sebagainya). Sehingga revitalisDasi berarti membangkitkan kembali vitalitas. Dapat diambil kesimpulan revitalisasi adalah usaha-usaha untuk menjadikan sesuatu itu menjadi penting dan perlu sekali.

Secara pengertian etimologi, kata dakwah berasal dari يدعوة -دعاع seruan, ajakan, atau panggilan. Seruan yang dimaksud bertujuan untuk mengajak seseorang baik dalam melakukan sesuatu kegiatan atau dalam merubah pola serta kebiasaan hidup. berasal dari kata seruan, dakwah mempunyai banyak definisi yang sangat luas tidak terbatas pada pada agama.

Dalam Al-Qur'an kata dakwah memiliki fungsi yang bermacam-macam. Terdapat sebanyak 198 kali kata dakwah dalam Al-Qur'an yang semuanya tidak merujuk pada satu arti akan tetapi merujuk pada beberapa arti kata. Kata dakwah menunjukkan pada ajakan yang dilakukan seseorang agar orang lain mengikuti keinginan. Ajakan bisa melalui ceramah atau nasihat secara individu agar seseorang bersedia untuk melakukan apa yang dikehendaki si Pendakwah.

Pengabdian ini menggunakan model penelitian berbasis masyarakat (Community Based Reasearch). Community Based Research (CBR) adalah sebuah penelitian yang dilakukan berdasarkan komitmen dari sebuah komunitas / masyarakat untuk memberikan dukungan sumber daya, kekuatan, dan yang paling penting keterlibatan dalam proses penelitian untuk menghasilkan produk 
penelitian yang bermanfaat bagi komunitas dan juga para peneliti. Inisiatif penelitian bisa juga datang dari para ilmuwan atau peneliti setelah melihat permasalahan dan potensi yang ada dalam masyarakat, untuk memberi solusi rumusan teknis instrumentatif penyelesaian masalah yang dihadapi masyarakat, baik disadari atau tidak oleh masyarakat, sehingga masyarakat/ mitra dampingan terbawa dalam arus perubahan dan kemajuan. Pengabdian ini dilaksanakan selama lima bulan penuh.

Dalam penentuan mitra pengabdian digunakan sampel purposive sampling, Pola penentuan sampel ini ada beberapa kriteria yang dijadikan alasan. Syarat utama yang harus dimiliki, yaitu masjid aktif memiliki agenda kegiatan keagamaan ( pengajian) yang rutin dan masjid harus memiliki admin yang bisa mengoperasikan website.

Dua syarat tersebut yang dijadikan kriteria dalam penentuan pemilihan masjid dampingan dalam penelitian ini. Disamping itu setidaknya memiliki beberapa pertimbangan yaitu factor kesejarahan atau masjid yang sudah dikenal masyarakat secara luas. Sehingga dengan tujuan-tujuan tertentu tersebut dipilih 8 Masjid dampingan yang dijadikan Subjek dampingan yaitu :

1. Masjid Agung Jawa Tengah (MAJT)

2. Masjid Kauman/Masjid Agung Semarang

3. Masjid Baiturrahman Semarang

4. Masjid Al-Azhar Perum Permata Puri Ngaliyan

5. Masjid Miftahul Jannah Perum Taman Bringin Indah Ngaliyan

6. Masjid Jami Muhajirin Perum Jatisari Mijen Semarang

7. Masjid Al-Muttaqin Kaliwungu Kendal

8. Masjid Al Burhan Salatiga

Langkah-langkah dalam Penelitian berbasis CBR meliputi empat langkah yang secara sirkular tampak pada gambar 1. Langkah pertama, Laying Foundation (Meletakkan Dasar). Kunci utama CBR adalah melibatkan komunitas dalam keseluruhan proses penelitian. Oleh karena itu, sejak awal mendesain penelitian, komunitas bersama-sama peneliti sudah harus mendiskusikan tujuan penelitian dan melakukan pembagian peran masingmasing, baik dari unsur peneliti maupun komunitas. Hal ini perlu dilakukan sampai terjadi kesepakatan. Hal yang penting dipersiapkan pada tahap ini adalah pengenalan terhadap gambaran umum kehidupan dan kondisi komunitas mitra penelitian melalui proses inkulturasi sebagai upaya trust building masing-masing pihak yang terlibat. Untuk itu, implementasi prinsip jalinan kemitraan menjadi sesuatu yang tak terelakkan. Bagi CBR - pengelolaan dan keberlanjutan kemitraan diasumsikan sebagai hal yang penting karena proses riset 
membutuhkan pemahaman yang lebih baik atas perubahan sosial pada komunitas. Aktifitas yang terkait negotiating goals and roles tersebut dapat dilakukan melalui teknik mengorgainisir stakeholders serta memperjelas perannya masingmasing, mengorganisir dan mengidentifikasi asumsi yang berkembang dalam komunitas untuk diteliti, memperjelas konteks penelitian, serta menentukan tujuan akhir dari penelitian.

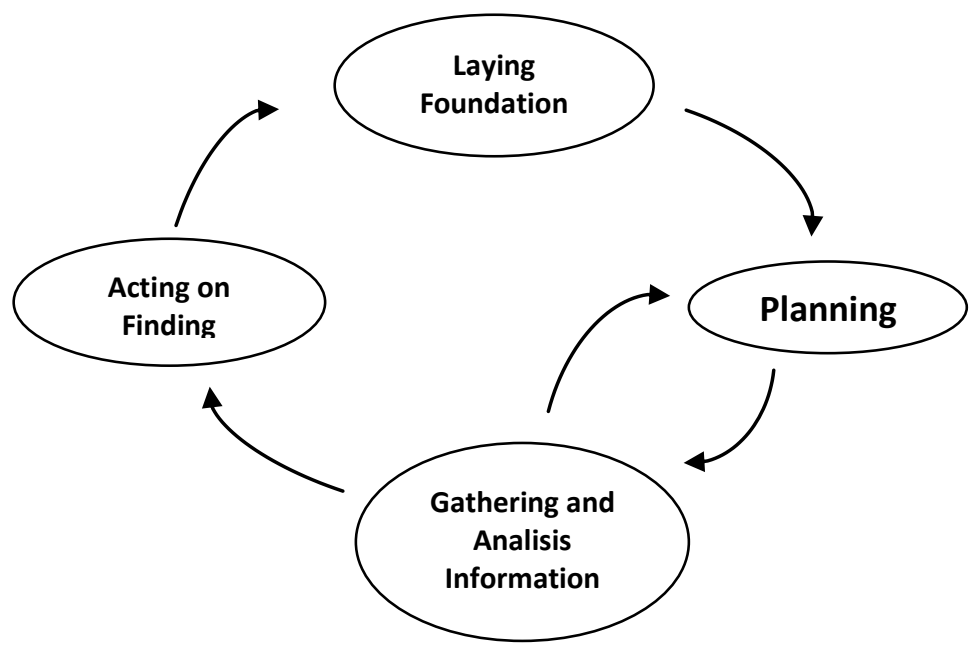

Gambar 1 Siklus CBR

Dalam tahap ini peneliti dan mitra dampingan melakukan identifikasi, menyamakan persepsi pada tujuan yang di inginkan. Dari 8 Masjid peneliti melakukan menyamakan persepsi sehingga muncul trust building, dan kesefahaman untuk mencapai tujuan yang di inginkan.

Langkah kedua, Planning. Tahap ini adalah tahap negotiating perspectives to illuminate. Artinya ada kesepahaman perspektif untuk mencerahkan. Pada tahap ini beberapa asumsi yang berhasil diidentifikasi pada tahap awal ditentukan dan dipilih mana yang menjadi prioritas utama untuk dijadikan pertanyaan penelitian, metode apa yang akan digunakan untuk menjawab pertanyaan penelitian, bagaimana menampung pendapat stakeholder, mempertimbangkan kendala waktu dan biaya dan merencanakan teknik analisisnya. Pada tahap ini adalah mendiskusikan solusi yang direncanakan untuk memberikan pencerahan, rancangan solusi yang disepakati untuk menyelesaikan masalah. 
Langkah ketiga, Pengumpulan dan Analisis Data (Gathering and Analysis Information). Tahap ini disebut juga negotiating meaning and learning, merupakan proses pemaknaan dan pembelajaran melalui mengumpulkan, menganalisis dan mengintrepretasi data. Pengumpulan data dapat dilakukan dengan beberapa cara dan alat misalnya dengan melakukan depth interview, observasi, dokumentasi, FGD, story telling, mapping komunitas, kalender musim, trend change, dan matriks ranking.

Dalam Tahap ini dilakukan FGD dan Workshop yang merupakan. Hasil dari FGD dan Workshop di recheck ulang terhadap tahap planning, sehingga hasil selalu dalam bentuk siklus untuk menghasilakn hasil yang terbaik.

Lengkah terakhir, keempat, Tindak Lanjut Penemuan (Acting onx Finding). Tahap ini merupakan tahap memobilisasi pengetahuan dan masyarakat terhadap hasil riset. Hal ini dapat dilakukan melalui berbagi informasi dan tindakan atas hasil riset. Menyampaikan hasil riset kepada masyarakat. Hasil dari penelitian dipublikasikan secara luas kepada masyarakat, dalam kasus ini Android yang telah dibuat dipublikasikan melalui facebook, instagram, whatshap dan diseminasi dalam forum DMI, takmir masjid maupun lainnya.

\section{HASIL PENGABDIAN DESAIN DAKWAH BERBASIS ANDROID}

Dari delapan Masjid yang menjadi mitra Dampingan hanya dua masjid yang sudah memiliki website yaitu MAJT dan Masjid Baiturrohman. Ada beberapa masjid yang sudah memiliki channel youtube yaitu MAJT, Masjid Baiturrohman, dan masjid Al-Azhar perum Permata puri. Berikut ini tabel kepemilikan website oleh masjid-masjid mitra dampingan.

Tabel 1 Keberadaan Website Masjid Mitra Dampingan

\begin{tabular}{clc}
\hline \hline No & \multicolumn{1}{c}{ Nama-Nama Masjid } & Website Masjid \\
\hline \hline 1 & Masjid Agung Jawa Tengah (MAJT) & Ada \\
\hline 2 & $\begin{array}{l}\text { Masjid Kauman/Masjid Agung } \\
\text { Semarang }\end{array}$ & Belum \\
\hline 3 & Masjid Baiturrahman Semarang & Ada \\
\hline 4 & $\begin{array}{l}\text { Masjid Al-Azhar Perum Permata Puri } \\
\text { Ngaliyan }\end{array}$ & Belum \\
\hline 5 & $\begin{array}{l}\text { Masjid Miftahul Jannah Perum Taman } \\
\text { Bringin Indah Ngaliyan }\end{array}$ & Belum \\
\hline 6 & $\begin{array}{l}\text { Masjid Jami Muhajirin Perum Jatisari } \\
\text { Mijen Semarang }\end{array}$ & Belum \\
\hline 7 & Masjid Al-Muttaqin Kaliwungu & Belum \\
\hline
\end{tabular}




\begin{tabular}{lll}
\hline & Kendal & \\
\hline 8 & Masjid Al Burhan Salatiga & Belum \\
\hline
\end{tabular}

Hasil dari wawancara dari beberapa masjid mengatakan bahwa pola dakwah masjid masih manual, hanya ketika diadakan pengajian dan kegiatankegiatan lainnya. Sebelum dijadikan subjek dampingan, beberapa masjid diadakan dialog diskusi dengan ketua takmir atau yang mewakili. Dalam diskusi semua masjid dampingan sangat setuju dan sangat senang dengan format yang kami tawarkan. Yaitu semua masjid mengirimkan 2 peserta yang menjadi peserta workshop/FGD untuk dilatih tentang pengelolaan website.

Tabel 2 Jadwal Pelaksanaan FGD/Workshop

\begin{tabular}{lll}
\hline \hline No & Tanggal pelaksanaan & Materi \\
\hline \hline 1 & 14 Juli 2019 & $\begin{array}{l}\text { FGD tentang tentang fungsi Masjid oleh DMI } \\
\text { Jawatengah }\end{array}$ \\
\hline 2 & 21 Juli 2019 & Workshop I tentang pengelolaan masjid \\
\hline 3 & 21 Juli 2019 & Workshop tentang pengelolaan website masjid \\
\hline 4 & 28 juli 2019 & $\begin{array}{l}\text { Workshop tentang pelatihan literasi website } \\
\text { masjid } \\
\end{array}$ \\
& Dan editing audio video \\
\hline
\end{tabular}

Tahap awal adalah planning. Pada Tahap ini melakukan negotiating perspective to illuminate yaitu adanya kesefahaman untuk mencari solusi dari permasalahan. Pada tahap ini adanya kesepakatan bersama untuk mencari solusi atas permasalahn yang dihadapi oleh masjid. Setelah mengetahui bahwa pada era milenial ini ternyata masjid-masjid yang menjadi mitra dampingan belum memiliki website yang bertujuan untuk menglobalkan dakwah masjid maka peneliti dan mitra dampingan sepakat untuk pembuatan website masjid dan mengikuti pelatihan, workshop pengelolan website masjid. Maka disepakatilah untuk mengadakn pembelian domain hosting dan mengikuti workshop tentang manajemen website, literasi konten website dan editing foto video. Secara umum hasil kesepakatan tersebut antara lain:

a) Perlu diadakan website masjid, sekaligus dilakukan pelatihan pendampingan dalam manajemen website masjid

b) Website tersebut meliputi website dan juga literasi dalam penampilan konten dakwah masjid

c) Siap mengirimkan delegasi mewakili takmir untuk dididik mengenai pengelolaan website masjid

d) Teknis pelaksannan tersebut kemudian di rencanakan oleh tim seperti dalam tabel dibawah ini 
Langkah beriktunya Pengumpulan dan Analisis Data ( Gathering and Analysis Information ). Pada tahap ini merupakan tahap do (pelaksanaan) dalam penelitian ini yaitu sesui dengan tabel 4. FGD menjelaskan tentang fungsi masjid yang di sampaikan oleh sekretaris Dewan masjid jawa tengah yaitu DR. KH. Multazam Ahmad, M.Si beliau memeberikan deskripsi tentang tantangan dan yang dihadapi oleh para takmir masjid pada era milenial ini. Demikian juga kreatifitas dari takmir masjid yang harus selalu dilakukan untuk melakukan dakwah yang emngikuti perkembangan zaman.

Tabel 3. Tabel Pengiriman Delegasi Oleh Takmir Masjid

\begin{tabular}{|c|c|c|}
\hline No. & Asal Masjid & Peserta \\
\hline \multirow{2}{*}{1} & \multirow{2}{*}{ Masjid Agung Jawa Tengah } & Beny Arief H. \\
\hline & & Musyafak \\
\hline \multirow{2}{*}{2} & \multirow{2}{*}{ Masjid Besar Kauman Semarang } & Titok Purwanto \\
\hline & & Agus Setiawan \\
\hline \multirow{2}{*}{3} & \multirow{2}{*}{ Masjid Baiturrahman } & Ahmad Junianto \\
\hline & & Asrul Sani \\
\hline \multirow{2}{*}{4} & \multirow{2}{*}{$\begin{array}{l}\text { Masjid Al-Azhar Permata Puri Ngaliyan } \\
\text { Semarang }\end{array}$} & Slamet Riyanto \\
\hline & & Ahmad Gusfatokul \\
\hline \multirow{2}{*}{5} & \multirow{2}{*}{$\begin{array}{l}\text { Masjid Al-Muhajirin Jatisari Mijen } \\
\text { Semarang }\end{array}$} & Fachriza D. A. \\
\hline & & Rizqi Kurnia R. \\
\hline \multirow{2}{*}{6} & \multirow{2}{*}{ Masjid Al-Muttaqin Kaliwungu Kendal } & Fahruddin Anwar \\
\hline & & Hardiyanto \\
\hline 7 & Masjid Burhan Salatiga & - \\
\hline 8 & Masjid Miftahul Jannah & \\
\hline
\end{tabular}

Kegiatan Forum Group Discussion (FGD) dimuat dalam laman Koran Harian Suara Merdeka versi cetak dan on line dengan judul Tantangan Masjid Hadirkan Ceramah Menarik Bagi Kaum Milenial. Sedangkan yang datang pada acara FGD tersebut tidak semua masjid. 2 Masjid belum mengirimkan delegasi, sehingga hanya di wakili oleh 6 masjid saja sesuai tabel 3.

Kegiatan selanjutnya mengadakan Workshop I dan II tentang pengelolaan website masjid. Pada worksop yang pertama ini dilakukan pemetaan tentang keberadaan masjid. Workshop ini sebenarnya kelanjutan dari FGD tentang fungsi masjid di era milenaial. Pada pertemuan ini dihadiri oleh admin dari takmir masjid, sejumlah Pada pertemuan ini dihadiri 7 perwakilan masjid. Setelah dilakukan diskusi ternyata dapat dipetakan maka dari 6 masjid dibelikan/disewakan hosting dan domain oleh tim pengabdian. Sambil 
membawa scan fotokopi KTP dan susunan pengurus yang diberikan kepada tim. Subjek dampingan sepakat untuk membuat website masjid. Dengan sewa hosting dan domain. Disepakati sebagai berikut. Sesuai hasil rapat akhrinya disepakati nama-nama website masjid yang tampak pada table 4. Setelah adanya website masjid dari masing-masnig masjid maka langkah selanjutnya adalah manajemen website.

Manajemen website yaitu diadakan workshop yang kedua yaitu mengenai pengelolaan website, meliputi pengaturan tampilan, pengaturan menu-menu tampilan, serta desain tampilan pada website masjid. Pada workshop yang kedua ini menentukan baik dan tidaknya tampilan website pada masing masing masjid. Apabila ada yang belum maksimal dan kurang maksimal dalam desain konten masjid maka diadakan konsultasi klinis dengan berbagai admin masjid yang menjadi mitra dampingan.

Tabel 4 Daftar Kepemilikan Website Masjid

\begin{tabular}{clc}
\hline \hline No & \multicolumn{1}{c}{ Nama-Nama Masjid } & $\begin{array}{c}\text { Keberadaan website } \\
\text { Masjid }\end{array}$ \\
\hline \hline 1 & $\begin{array}{l}\text { Masjid Agung Jawa Tengah } \\
\text { (MAjT) }\end{array}$ & \multicolumn{1}{c}{ Ada } \\
\hline 2 & $\begin{array}{l}\text { Masjid Kauman/Masjid Agung } \\
\text { Semarang }\end{array}$ & $\begin{array}{c}\text { www. } \\
\text { masjidagungsemarang.or.id }\end{array}$ \\
\hline 3 & Masjid Baiturrahman Semarang & \multicolumn{1}{c}{ Ada } \\
\hline 4 & $\begin{array}{l}\text { Masjid Al-Azhar Perum } \\
\text { Permata Puri Ngaliyan }\end{array}$ & www.permataalazhar.or.id \\
\hline 5 & $\begin{array}{l}\text { Masjid Miftahul Jannah Perum } \\
\text { Taman Bringin Indah } \\
\text { Ngaliyan }\end{array}$ & www.miftahuljannah.or.id \\
\hline 6 & $\begin{array}{l}\text { Masjid Jami Muhajirin Perum } \\
\text { Jatisari Mijen Semarang }\end{array}$ & www.masjidlestari.or.id \\
\hline 7 & $\begin{array}{l}\text { Masjid Al-Muttaqin Kaliwungu } \\
\text { Kendal }\end{array}$ & www.almuttaqinklw.or.id \\
\hline 8 & Masjid Al Burhan Salatiga & www.masjidalburhan.or.id \\
\hline
\end{tabular}

Guna menunjang pengelolaan website, dilaksanakan workshop teknik penulisan dan workshop teknik editing foto. Pertama, workshop teknik penulisan. Yang tidak kalah pentingnya adalah pelatihan narasi, bahgaimana cara menulis supaya menarik bagi pembaca. Wokshop ini mempelajari secara detail teknik penulisan, bagaimana cara membuat headline, membuat narasi isi dalam suatu kegiatan dakwah masjid. Demikian trikitrik dan kiat-kiat dalam menulis 
dikupas tuntas dalam wokshop ini. Adapun yang bertindak sebagai nara sumber dalm penelitian ini adalah seorang wartawan senior dari media suara merdeka yaitu Royce wijaya Setya Putra, S.Kom.

Kedua, Workshop Teknik Editing Foto. Workshop Teknik Editing Audio dan Video di berikan secara detail oleh seorang pakar editing Audio video. Workshop ini bertujuan memeberikan bekal secara utuh dalam hal teknik editing gambar dan video, sehingga gambar/ image yang diambil sebelum di upload dalm website masjid bener bener sebuah foto yang terbaik. Adapun narasumber yang memberikan materi ini adalah Bapak Bimanstar.

Hasil dari website tersebut dapat dipantau dari kunjungan harian dari berbagai masjid yang menjadi masjid mitra dampingan. Website-website masjid pada table 5 tersebut dihubungkan dalam suatu aplikasi andoid yang bisa di buka dalam hp. Laman andoid tersebut bisa dibuka di playstore dan laman berikut: https://play.google.com/store/apps/details?id=mmf.dev.dakwahonline dengan tampilan gambar pada gambar 1.

Tabel 5 Jumlah User dan view website masjid

\begin{tabular}{clcc}
\hline No & Website Masjid & Jumlah User (65 hari) & View \\
\hline 1 & almuttaqinklw.or.id & 305 & 1368 \\
\hline 2 & masjidlestari.or.id & 488 & 1863 \\
\hline 3 & miftahuljannah.or.id & 537 & 6306 \\
\hline 4 & permataalazhar.or.id & 160 & 831 \\
\hline 5 & ypkpi-jateng.org & 5714 & 5279 \\
\hline 6 & masjidagungsemarang.or.id & 128 & 171 \\
\hline 7 & majt.or.id & 533 & 839 \\
\hline 8 & masjidalburhan.or.id & 530 & 1612 \\
\hline
\end{tabular}

Dengan menginstal aplikasi ini maka konten dakwah masjid bisa di di buka pada HP dengan memilih konten dari masjid yang kita inginkan. Dari hasil konten website yang telah di upload maka kemudian dibuatlah aplikasi android, dengan aplikasi tersebut maka setiap orang yang memiliki hp bisa menginstal dan menikmati dan memilih konten masjid mana yang mau di pilih.

Hasil dalam pengabdian ini selain Aplikasi Andoid yang bisa di lihat secara realtime jumlah pengunjung, jumlah pengguna, dan dakwah masjid tersebut bisa di nikmati secara langsung oleh public. Dengan cara menginstal aplikasi dakwah 
online maka website dari 8 masjid dampingan akan dapat dilihat secara detail. Dengan mengakses website masjid dampingan maka akan dapat menikmati dakwah masjid yang menjadi mitra dampingan.

\section{KESIMPULAN}

Telah dilaksanakan pendampingan desain website masjid, pengelolaan website dan manajemen konten website pada delapan masjid yaitu Masjid alMuttaqin Kaliwungu, masjid Al Azhar Permata Puri, Masjid Miftahul Jannah Perum Bringin Indah Ngaliyan, Masjid Muhajirin BSB Jatisari, Masjid Al-Burhan Salatiga, Masjid Agung Semarang, Masjid Baiturrahman Semarang, dan Masjid Agung Jawa Tengah. Dari Delapan masjid hanya dua masjid yang sudah memiliki website yaitu Masjid Baiturahman Semarang dan MAJT. Hasil dari pendampingan ini menghasilkan desain yang cukup baik dan diharapkan admin website masjid selalu melakukan updating konten dakwah masjid. Website yang telah di desain oleh admin masjid tersharing dalam satu aplikasi " dakwah online" dengan

laman https://play.google.com/store/apps/details?id=mmf.dev.dakwahonline.

Sehingga user bisa me menikmati dakwah masjid dari delapan masjid tersebut.

\section{DAFTAR PUSTAKA}

Agung, Leo. (2011). Aplikasi Web Database dengan Dreamwever dan PHP-MySQL. Yogyakarta: Andi.

Basit, Abdul, 2009, Strategi Pengembangan Masjid bagi Generasi Muda,Jurnal Dakwah ; Purwokerto

Creese, Gillian Laura, and Wendy Mae Frisby. 2011, Feminist Community Research: Case Studies and Methodologies. Vancouver: UBC Press

De Sousa Santos, Boaventura. 2007, Cognitive Justice in a Global World Prudent Knowledges for a Decent Life. Lanham: Lexington Books

Demange, E., E. Henry, A. Bekelynck, M. Préau. -A Brief History of Community-Based Research.\| Demange, E., Henry, E., Préau, 
Denzin, Norman K, and Yvonna S Lincoln. , 2005. The SAGE Handbook of Qualitative Research. Thousand Oaks: Sage Publications

Budiati, Indah dkk, 2018, Profil Generasi Milenial Indonesia, KPPPA, Jakarta

Pressman, R S. (2002). Rekayasa Perangkat Lunak Pendekatan Praktisi (Alih bahasa: CN Harnaningrum). Yogyakarta: Penerbit Andi.

Sidik, B. 2012. Framework Codeigniter. Bandung: Informatika.

Simarmata, Janner. (2006). Pengenalan Teknologi Komputer dan Informasi. Yogyakarta: Andi Offset.

Sugiyono. 2012. Metode Penelitian Pendidikan: Pendekatan Kuantitatif, Kualitatif, dan R\&D. Bandung: Alfabeta.

Tim Penyusun UIN Sunan Ampel,2015. Community Based Research, LP2M UIN Sunan Ampel

www.wikipedia.com

Yakub. 2012. Pengantar Sistem Informasi. Yogyakarta: Graha Ilmu.

Yani, Ahmad, 2012, Panduan memakmurkan Masjid, Gema Insani Press, 